\title{
Vitamin D3 as a Powerful Immunoregulator - Cause or Consequence of Disbalance?
}

\author{
Miskic B ${ }^{* 1}$, Rajkovaca $I^{2}$ and Cosic $\mathbf{V}^{1}$ \\ ${ }^{1}$ Faculty of Dental Medicine and Health Osijek, University of Josip Juraj Strossmayer, Croatia \\ ${ }^{2}$ Department of gastroenterology, endocrinology and diabetology, General hospital Dr. Josip Benčević, Croatia
}

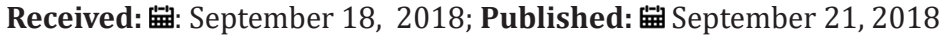

*Corresponding author: Miskic B, Faculty of Dental Medicine and Health Osijek, University of Josip Juraj Strossmayer, Croatia

\section{Opinion}

For the last two decades the role of Vitamin D3 has been recognized not only as a regulatory component of a bone - kidney metabolism, but also as an important immunomodulator [1]. Low serum levels of vitamin D are detected before an egzacebation in rheumatic diseases: psoriatic arthritis, rheumatoid arthritis and ankylosing spondylitis [2,3]. Same has been shown in exacerbation of Hashimoto's thyroiditis and ulcerative colitis, multiple sclerosis, in some kinds of cancer, in cardiovascular diseases and diabetes mellitus type 2 [4-8]. Also, low levels of vitamin D3 have been confirmed many years before onset of autoimmune disease $[2,9]$.

Recent studies have investigated new role of vitamin D in intracellular processes. Dankers et al. [10] showed possible molecular mechanisms in which vitamin D can interphere intracellular mechanisms [10]. It is known that actions of vitamin D3 are mediated by the vitamin D receptor (VDR), a ligand-activated transcription factor that functions to control gene expression [11]. VDR protein is comprised of three regions, an $\mathrm{N}$-terminal dual zinc finger DNA binding domain, a C-terminal ligand-binding activity domain and an extensive region that links the two functional domains of this protein together [12].

When vitamin D3 interacts with VDR surface, VDR binds to regulatory regions of target genes and acts to nucleate the formation of large protein complexes whose activation is essential for changes in transcription [13]. These actions result in the expression of networks of target genes that control highly complex actions like growth, differentiation and activity of immune system cells, skin cells and bone metabolism as well as many other functions that are devoted to vitamin D [14]. Evans et al. [15] showed multiple binding patterns throughout heterodimerization or overlaps of vitamin D responsive elements (VDREs) in the DNA. It is considered that conformational change between retinoid $X$ receptor (RXR) and vitamin $\mathrm{D}$ receptor (VDR) through their heterodimerization can activate different signaling pathways resulting in production of a large number of proteins involved in cell function [15].
All these interactions depend on vitamin D serum levels because nuclear receptors, such as VDR, can autoregulate their own activity [15], but it still remains unknown if and what receptor conformational changes are responsible for production of mRNA which is liable for protein synthesis. It's considered that maintenance of low serum levels of vitamin D and its metabolites regulates activation of immune system cells such as monocytes, dendritic cells, B- and T- Cells, macrophages, regulatory $\mathrm{T}$ cells and also regulates activation of $\mathrm{NK}$ cells and pro-inflammatory cytokines [16-22].

Even though we know many facts about protective effects of vitamin D, 2,5 million people have been confirmed for having vitamin D deficiency. Air pollution, short sun exposure, use of different types of medications and use of sun blockers, poor nutritional intake and sedentary lifestyle are causes of this condition [23]. In our studies we confirmed that lower levels of vitamin D are found in diabetes type 2 population with or without acute coronary syndrome [24,25], autoimmune thyroiditis [26], glaucoma [27] and in recurrent urinary infections in postmenopausal women.

Also, there is a study showing how vitamin D supplementation during conception and pregnancy can improve fertility and gestation in women with Hashimoto thyroiditis [28]. Despite of small number of participants we hope that it can contribute to improve our knowledge of vitamin D important role in these conditions. According to previous studies that investigated vitamin D-regulated intracellular pathways, it is still unknown if vitamin D3 deficiency is caused by its poor intake and reduction of sunlight exposure or is it cellular microenvironment that regulates these pathways causing vitamin D deficiency even though its intake is normal.

Many previously published studies have limiting factors such as small sample size, inconsistencies in the study protocols, unknown serum levels of vitamin D and unclearly defined objectives of the studies (mostly clinical outcome based studies). 
We think that its important not only to establish vitamin D serum levels in acute event, it would be useful to know its serum levels some weeks before the event occurs. Estimated level of vitamin D is only current states indicator. We still don't know which serum level is a trigger for cell state change and how long it takes for a certain serum level to cause conformational changes of receptors following changes in protein synthesis. Answers to those questions can be found in the newest intracellular researches including VDR and its molecular mechanism of action at target genes and how vitamin D3-activated VDR modulates the expression of genes at both single gene and also at the level of gene networks [11].

For the detailed assessment of modulation effects of available vitamin D3 metabolites at given serum concentration it is necessary to monitor VDR and RXR intracellular activity on a level of a certain cell function gene activator and repressor [2]. Only randomized controlled trials which will study intrageneric mutations mentioned previously can give us the answer if vitamin D is the main supervisor of intracellular metabolism or is it one of many cofactors. There is a growing number of studies like this showing unexpected results suggesting that vitamin D-regulated pathways are even more complex than we previously thought.

\section{References}

1. Di Rosa M, Malaguarnera M, Nicoletti F, Malaguarnera L (2011) Vitamin D3: A HelpfulImmuno-Modulator. Immunology 134(2): 123-139.

2. Hiraki LT, Arkema EV, Cui J, Malspeis S, Costenbader KH, et al. (2014) Circulating 25-hydroxyvitamin D level and risk of developing rheumatoid arthritis. Rheumatology (Oxford) 53(12): 2243-2248.

3. Handel AE, Sandve GK, Disanto G, Berlanga-Taylor AJ, Gallone G, et al (2013) D receptor ChIP-seqinprimary CD4+ cells: Relationship to serum 25-hydroxyvitamin D levels and auto immune disease. BMC Med 11: 163.

4. Tizaoui K, Kaabachi W, Hamzaoui A, Hamzaoui K (2015) Association between vitamin $\mathrm{D}$ receptor polymorphisms and multiple sclerosis: Systematic review and meta-analysis of case-control studies. Cell MolImmunol 12(2): 243-252.

5. Feldman D, Krishnan AV, Swami S, Giovannucci E, Feldman BJ (2014) The role of vitamin $\mathrm{D}$ in reducing cancer risk and progression. Nat Rev Cancer 14(5): 342-357.

6. Chen S, Law CS, Grigsby CL (2011) Cardiomyocyte-specific deletion of the vitamin D receptor gene results in cardiac hypertrophy. Circulation 124(17): 1838-1847.

7. Yiu YF, Yiu KH, Siu CW (2013) Randomized controlled trial of vitamin D supplement on endothelial function in patients with type 2 diabetes. Atherosclerosis 227(1): 140-146.

8. Li X, Liao L, Yan X, Huang G, Lin J, et al. (2009) Protective effects of 1-alpha-hydroxyvitamin D3 on residual beta-cell function in patients with adult-onset latent autoimmune diabetes (LADA). Diabetes Metab Res Rev 25(5): 411-416.

9. Zwerina K, Baum W, Axmann R, Heiland GR, Distler JH, et al, (2011) Vitamin D receptor regulates TNF-mediatedarthritis. Ann Rheum Dis 70(6): 1122-1129.

10. Dankers W, Colin ME, van Hamburg JP, Lubberts E (2017) Vitamin D in Autoimmunity: Molecular Mechanisms and Therapeutic Potential. Front Immunol 7: 697.

11. Pike JW, Meyer MB (2010) The vitamin D receptor: New paradigms for the regulation of gene expression by 1,25-dihydroxyvitamin D3. Endocrinol Metab Clin North Am 39(2): 255-269.
12. Rochel N, Wurtz JM, Mitschler A, Klaholz B, Moras D (2000) The crystal structure of the nuclear receptor for vitamin $\mathrm{D}$ bound to its natural ligand. Mol Cell 5(1):173-179.

13. Sutton AL, MacDonald PN (2003) Vitamin D: more than a "bone-a-fide" hormone. Mol Endocrinol 17(5): 777-791.

14. Bouillon R, Carmeliet G, Verlinden L, van Etten E, Verstuyf A, et al. (2008) Vitamin D and human health: Lessons from vitamin D receptor null mice. Endocr Rev 29(6): 726-776.

15. Evans RM, Mangelsdorf DJ (2014) Nuclear receptors, RXR, and the big bang. Cell 157(1): 255-266.

16. Brennan A, Katz DR, Nunn JD, Barker S, Hewison M, et al. (1987) Dendritic cells from human tissuesexpressreceptors for the immuno regulatory vitamin D3 metabolite, dihydroxycholecalciferol. Immunology 61(4): 457-461.

17. Kongsbak M, von Essen MR, Levring TB, Schjerling P, Woetmann A, et al. (2014) Vitamin D-binding protein controls T cell responses to vitamin D. BMC Immunol 15(1): 35.

18. Ferreira GB, Vanherwegen AS, Eelen G, Gutierrez AC, Van Lommel L, et al. (2015) Vitamin D3 induces tolerance in human dendritic cells by activation of intracellular metabolic pathways. Cell Rep 10: 711-725.

19. Korf H, Wenes M, Stijlemans B, Takiishi T, Robert S, et al. (2012) 1,25-dihydroxyvitamin D3 curtails the inflammatory and $\mathrm{T}$ cell stimulatory capacity of macrophages through an IL-10-dependent mechanism. Immunobiology 217(12): 1292-1300.

20. Bock G, Prietl B, Mader JK, Holler E, Wolf M, et al. (2011) The effect of vitamin $\mathrm{D}$ supplementation on peripheral regulatory $\mathrm{T}$ cells and $\beta$ cell function in healthy humans: A randomized controlled trial. Diabetes Metab Res Rev 27(8): 942-945.

21. Holick MF, Binkley NC, Bischoff-Ferrari HA, Gordon CM, Hanley DA, et al. (2011) Evaluation, treatment and prevention of vitamin D deficiency: Anendocrine society clinical practice guideline. J Clin Endocrinol Metab 96(7): 1911-1930.

22. Yang D, Anderson PH, Wijenayaka AR, Barratt KR, Triliana R, et al. (2017) Both ligand and VDR expression levels critically determine the effect of $1 \alpha, 25$-dihydroxyvitamin-D3 on osteoblast differentiation. J Steroid Biochem Mol Biol 177: 83-90.

23. Holick MF (2017) The vitamin D deficiency pandemic: Approaches for diagnosis, treatment and prevention. Rev Endocr Metab Disord 18(2): 153-165.

24. Miškić B, Knežević Praveček M, Ćosić V (2015) Vitamin D in diabetic patients with acute coronary syndrome. IOF Regionals - 3rd Middle East \& Africa Osteoporosis Meeting, Abu Dhabi, United Arab Emirates. Osteoporos Int 26(suppl 2): S439.

25. Knezević Pravaček M (2017) Correlation of serum concentrations of vitamin D and acute coronary syndrome in Brod-Posavina County. Doctoral disertation, University JJ Strosmayer, Faculty of Medicine, Osijek, Croatia.

26. Miškić B, Zukanović S, Ćosić V, Kneževic Praveček M, Jandrić Balen M, et al. (2016) Thyroiditis and Vitamin D. 3sss Annual Meeting of the European Thyroid Association, Copenhagen, Denmark. Eur Thyroid J 5(suppl 1): 124.

27. Vuković Arar Ž (2017) Association of serum vitamin D concentration and glaucomatous optic neuropathy in women. Doctoral disertation, University JJ Strosmayer, Faculty of Medicine, Osijek, Croatia.

28. Ćosić V, Miškić B (2005) Influence of Hormone Replacement Therapy on Vagina. $5^{\text {th }}$ European Congress on Clinical and Economic Aspects of Osteoporosis an Osteoarthritis, Roma, 2005. Osteoporos Int 16(suppl 3): S106. 


\section{ISSN: 2574-1241}

DOI: $10.26717 / B J S T R .2018 .09 .001771$

Miskic B. Biomed J Sci \& Tech Res

(c) (i) This work is licensed under Creative

Submission Link: https://biomedres.us/submit-manuscript.php

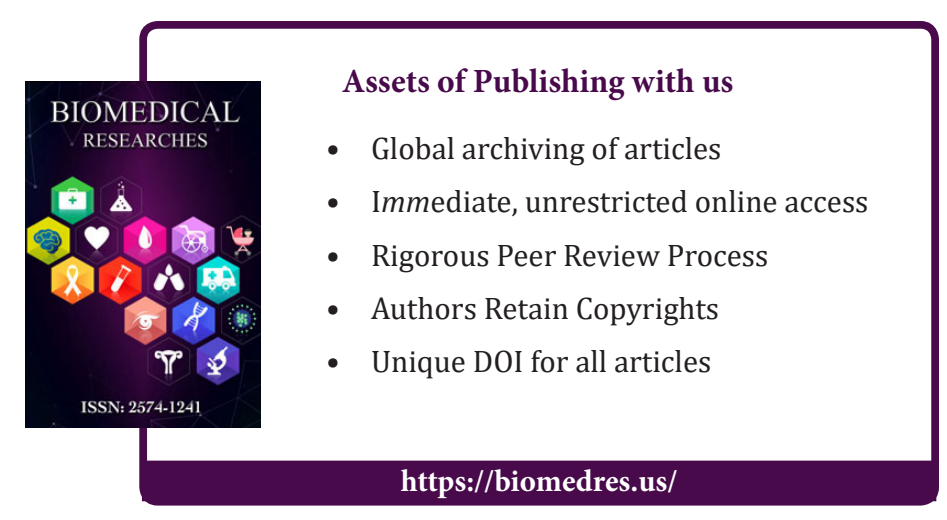

